\title{
WILD LIFE PRESERVATION IN BURMA
}

\author{
By U Tun Yin \\ Burma Civil Service (Retired)
}

The Legal Position.-The Wild Life Protection Act of 1936 is still in force. Section 6 affords complete protection to rhinoceros, tapir, peafowl, Argus pheasant and masked finfoot. But the provision to the said section reads as follows :-

"Provided that it shall not be an offence for any physician or druggist to possess or sell, or for any person to possess for private medical purposes rhinoceros blood or any preparation thereof."

This exception is a blot on an otherwise excellent Act, but it was essential for the reason that so many people in Burma have such implicit faith in the efficacy of rhinoceros blood for medicinal purposes. Had this exception been omitted, the Bill would probably not have been passed.

It is gratifying to learn that the Forest Law Amendment Committee has recommended the deletion of the proviso and to place the burden of proof on the possessor as in the case of possession of meat of wild animals during their close season. Early legislation is necessary to remove this "very large loophole for illicit dealings in rhinoceros blood, which means dead rhinoccros".

Under Section 7 no person shall hunt any of the following animals or knowingly possess or sell or buy them alive or dead or part or product thereof save under and in accordance with the conditions of a licence: "Elephant, bison, tsaing, thamin, serow and goral."

Section 8 prescribes a close scason from 15th June to 30th September for hog-decr, sambar and barking-deer and from 15th March to 30th September for all species of pheasant (except Argus pheasant), partridge, junglefowl, quail, wild duck and teal.

But the application of the Act to the States now comprising the Union of Burma is complicated and obscure. It does not apply, for instance, to the Kachin State. The few Sumatran rhinoceros which survive there are wholly unprotected, as are also, in that State, takin, musk-deer, panda, goral, scrow and other rare animals. If these are to be saved, not only must the Act be extended to the Kachin State, but the Kachin Fill Tribes Regulation and the IFkamti Long Administration Order must be amended. What is really required is that there 
should be a uniform wild life protection law throughout the Union of Burma.

At present the law is almost a dead letter for there is no central authority directly responsible for its enforcement. Civil officials have not only had many other claims on their time but have been afraid to take action against members of the armed forces and the peace guerrillas. Small blame to them, they would have been risking their lives.

\section{Wild Life Sanctuaries \\ Pidaung}

Constituted : 1018.

Area : 280 square miles.

Purpose : Sanctuary for clephant, gaur, tsaing, sambar, hog-(lecr, barkingdeer, pig, tiger, leopard, benr, pen-fowl, pheasant, partridge, quail.

Present Situation : Shot out during the war, but $n$ game staff of one hend keeper and five assistant keepers is now maintained (1055).

The Pidaung plain was known in old Burma as one of the best localities for gaur, tsaing, sambar and elephant. It used also to be famous for the herds of hog-deer that were found there. In July, 1948, a rhinoceros track was seen. 'The name originated from the open stretch of country or lwin covered with short grass situated to the north of Pidaung railway station on the Burma State Railways. The whole stretch of country over which the game was plentiful covers a very wide area containing several lwins separated by hills covered with densest evergreen jungle.

During my tenure of office as Deputy Commissioner, Myitkyina District (March, 1951-February, 1052), I camped in the sanctuary on four occasions and spent a total of cight days. I observed an elephant in Myanan lick on one evening in March, a sambar stag in Manaw lick for several minutes onc morning in May, a hog-decr stag feeding in Kason lwin one cvening, and a small herd of tsaing fecding in Pyawbwe lroin on the following morning in June. In the course of my wanderings I disturbed a gaur on one occasion, sambar and barking-decr on several occasions; peafowl and red jungle-fowl were secn all over the sanctuary. Black-breasted Kalij pheasant (Gennaus lathami) was seen once; hoolock gibbon (IIylobates hoolock Irarlan), the Chindwin langoor (Trachypithecus pileatus shortridgei Wroughton), the Burmese pig-tailed macaque (Macaca nemestrina Linnacus) and Phayre's leaf-monkey ('Trachypithecus phayrei phayrei Blyth) were also secn. The station master, Pidaung, had scen a leopard (black varicty) in the dry bed of a chaung near the railway station. 
Poaching was rife when I arrived in the District, but by enlisting the co-operation of the Officer Commanding, 1st Kachin Rifles, Battalion Commandant, U.MI.P., headmen and elders of the villages in the neighbourhood of the sanctuary, bringing up the game staff to pre-war strength and maintaining two gates, we succeeded in suppressing poaching completely by the middle of 1951. Salt was regularly put down in the salt licks and game had started to appear in the many lwins and salt licks when I left the district in February, 1952.

Soon after my return from Myitkyina, the Kachin Rifles were replaced by the Kayah Rifles. The Battalion Commandant, U.M.P., a keen conservationist, was recalled to the Army. The Chief Works Officer as well as the District Superintendent of Police who co-operated whole-heartedly in my humble efforts went on leave and, on expiry, returned to the Union Government.

There was also a change in the Kachin State Government. This was followed by a wave of serious crime in the Myitkyina District. Frequent poaching by parties of Army, Civil Police, and Union Military Police personnel in motor cars was detected by the game staff and reports made to the Deputy Commissioner, but no action was taken to stop it. $\Lambda$ gaur was shot about half a mile from Kason Chaung forest rest hut. The culprits were not apprehended. Kason Chaung is close to Nankyin village. Two assistant gamekeepers reside permanently in Nankyin village.

The new cantonment is located near the sanctuary. Without the co-operation of the Officer Commanding, we will not be able to stop poaching. Game is often driven out from the sanctuary and shot outside.

In August, 1953, U Maung Gale, a divisional forest officer interested in game preservation, was selected and sent to Myitkyina. He started at once to rehabilitate the sanctuary. Three Kachins were each sentenced to four months' rigorous imprisonment for shooting a gaur. Four armed guards were added to the existing staff of six gamekecpers. Roads were repaired and salt was deposited at all salt-licks regularly. Poaching almost ceased and game could be seen in increasing numbers, especially at the salt licks.

Unfortunately U Maung Gale was transferred before his work was completed. It is left to succeeding officers to bring the sanctuary back to its pre-war state.

The magnitude of this task can be to some extent understood by the following figures. They do not give the exact number 


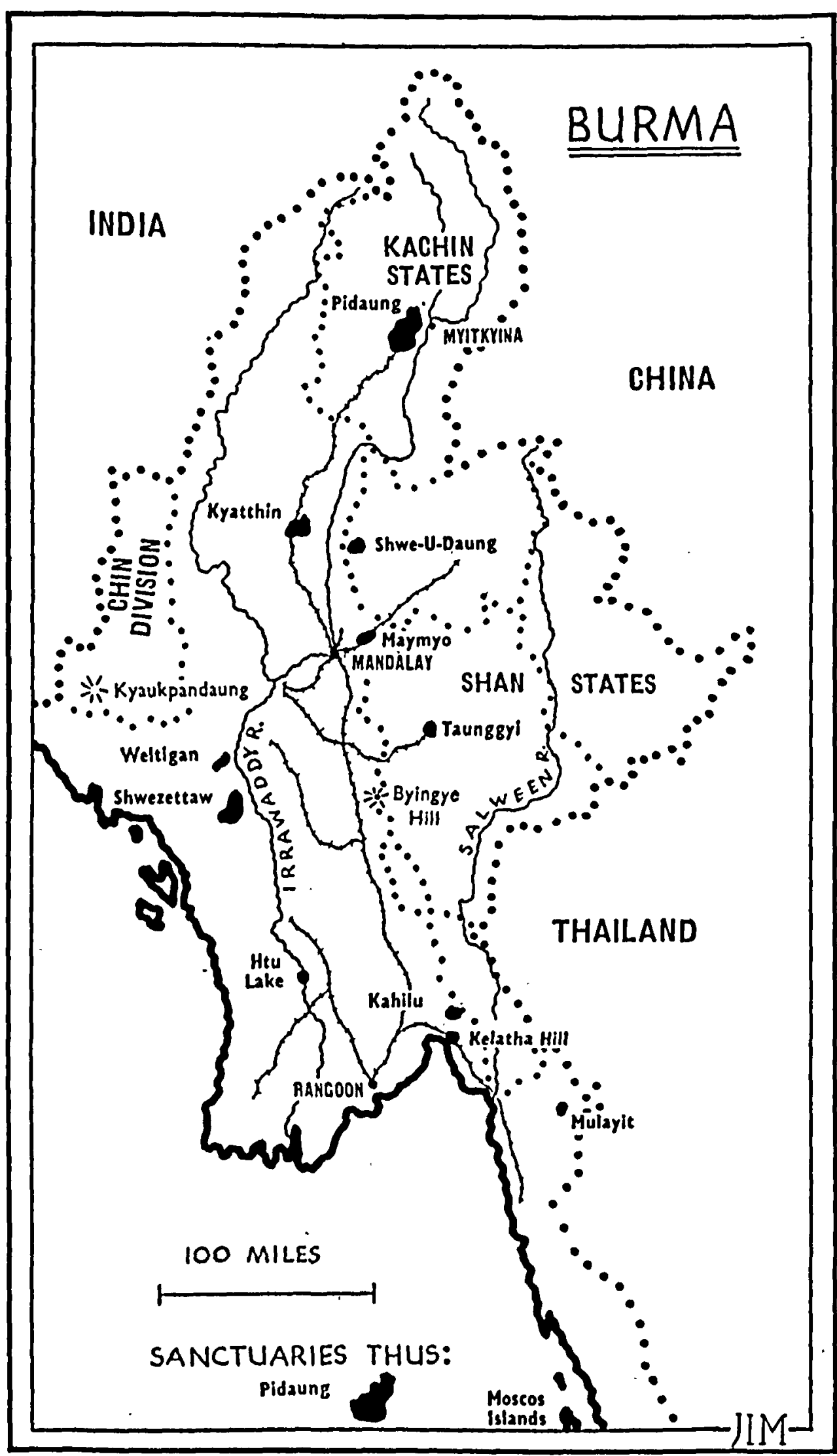


of any animal present in the sanctuary, but they do show the devastation of the war years and the gradual recovery of some species since 1948.

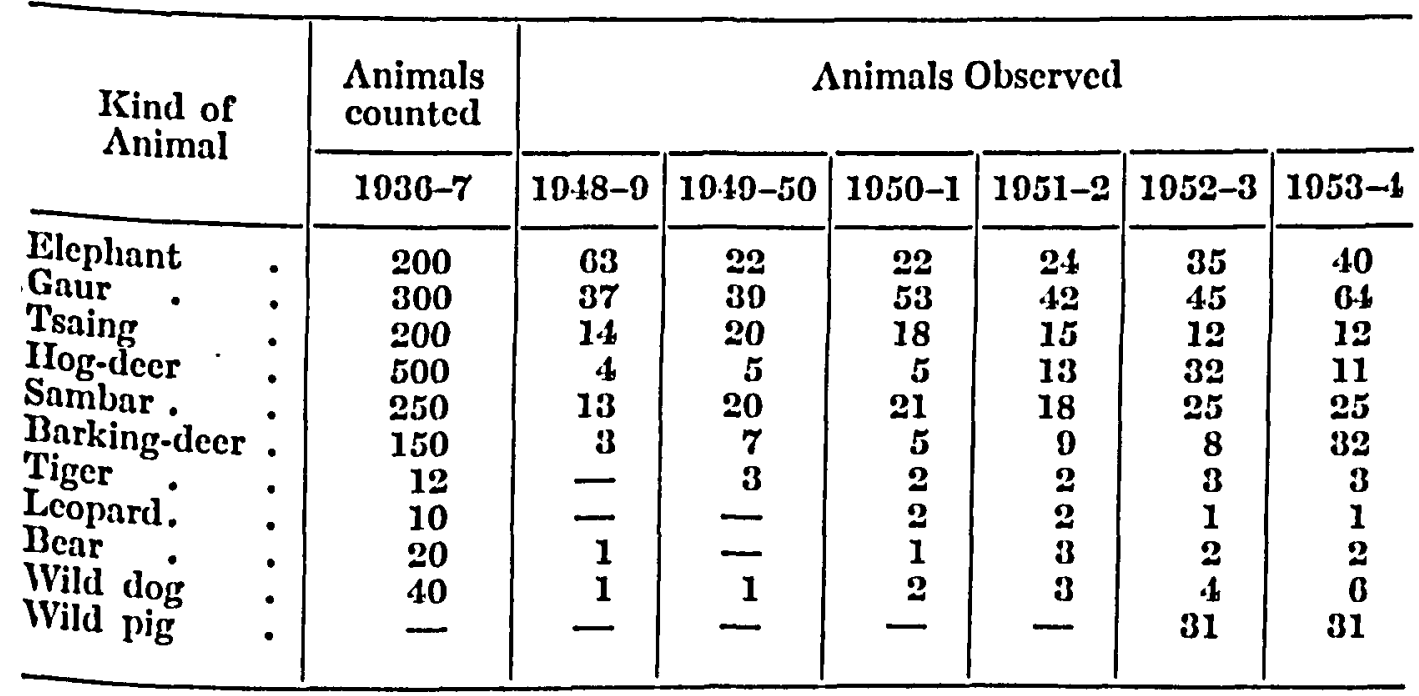

Since 1953 there has been an increase of animals, perhaps due to decrease in poaching. Seventy gaur were seen at onc time. A herd of four to eight tsaing and a fairly good number of hog deer have also been reported. If we could completely stop burning of charcoal in the area, both gaur and tsaing which have now taken to the hills might reappear. From the last report it appears that the hog-decr from the adjoining unclassed forests have come into the sanctuary. There may be more barking-deer than the figures given in the annual statements. The figures for elephant, gaur, tsaing, and sambar may be considered as very nearly correct.

Extensions to the Sanctuary.-In 1940, with a view to cxtending Pidaung Sanctuary to the south, Namse Reserve was formed. In 1942, at the time of the evacuation, plans were afoot to add also Uya-Hatha Reserves, Kawan Reserves and all the intervening unclassed forests. 'This contemplated addition to the Pidaung Sanctuary was well stocked with clcphant, gaur, tsaing, hog-decr, sambar, barking-decr, penfowl, partridge, pheasant and white-rvinged wood-duck. The large open grass plains in the area make it very suitable for further develop. ment into a place where wild animals and birds can be easily scen. If this projected extension can be accomplished, a sanctuary of approximately 600 squarc miles (including the existing Pidaung) will be brought into being.

Soon after his arrival in the division, U Maung Gale took 
up the question of rehabilitation of this sanctuary and submitted proposals in May, 1954. The proposals are now being examined in Rangoon and it is hoped that early orders will be issued for the settlement of the proposed extension.

The sanctuary can be developed into a national park in a short time and it would be an asset not only to the Kachin State but also to the Union of Burma.!

Constituted : 1930.

Taunggyi

Area : $0 \cdot 2$ square miles.

Purpose : Sanctuary for birds and barking-decr.

This sanctuary is practically surrounded by dense population. It is a good wild bird refuge but little more.

Constituted : 1028.

\section{Kahilu}

Area : 62 square miles.

Purpose: Sanctuary for Sumatran rhinoceros, scrow, sambar, barkingdecr, mouse decr, hog deer, jungle fowl.

In 1946-7 the tracks of two Sumatran rhinoceros were seen. In 1947-8 one animal was seen occasionally. No information later than 1948 is available.

Constituted : 1030.

MIulayil

Area : $53 \cdot 5$ square miles.

Purpose: Sanctuary for barking-decr, pig, tiger and leopard.

The. sanctuary is situated on the western slopes of the Dwana range which are uninhabited and likely to remain so. The highest point, Mount Mulayit, 6,823 fect, is a place of pilgrimage.

This is the first of a series of sanctuaries constituted with the support of the Buddhist monks. In an arca with such great range in elevation $(6,823$ feet down to 1,200 fect) the florn varies a great deal-from dense evergreen and moist deciduous forests, to hill forest and open grass screes on the highest slopes. There is therefore much variety of food for herbivorous fauna. The streams are all perennial and there are plenty of fish in the decp pools. The climate is wet with a rainfall of probably more than 200 inches per annum. This sanctuary was originally thought to contain rhinoceros, but so far their presence has not been cither proved or disproved. Tracks of a rhinoceros believed to be $R$. sondaicus were seen on the Dawna Range at 6,822 feet (1929-1930). 'The probability is that specimens may wander from time to time. 'The sanctuary was last visited in 1946-7 by the range officer who found tracks of gaur, mouse-decr, sambar, barking-deer, pig, bear, tiger and leopard. 
Constituted : 1018.

Shre-U-Daung

Area : 126 square miles.

Purpose: Sanctuary for Sumatran rhinoceros, elephant, gaur, tsaing, sambar, serow, barking-deer, pig, tiger, leopard, bear, peafowl, junglefowl, pheasant, partridge and quail.

In 1939 it was estimated that the sanctuary contained twelve or fifteen Sumatran rhinoceros. In April, 1948, the tracks of one, and a month old spoor of a cow with a calf at heel were seen. In May, 1948, one was seen and the divisional forest officer came to the conclusion that four or five were surviving.

In 1952 the writer was reliably informed that three Sumatran rhinoceros had been shot inside the sanctuary. One under a special permit issued to the Maha Devi for whom a physician had prescribed " a rhino-blood bath". Two others by the Shan hunters who had been entrusted with shooting the first.

The few surviving specimens are constantly harassed by poachers. The sanctuary is often disturbed by the presence of insurgents inside its boundaries.

The legend that the mountain spirits of Shwe-U-Daung do not like poachers is no longer heeded by the people resident in the neighbourhood of the sanctuary.

Constituted : 10.11.

Kyallhin

Area : 104 square miles.

Purpose : Sanctuary for thamin.

The constitution of this sanctuary is a departure from all existing ideas in that, for the first time, villages are included inside the sanctuary. Co-operation of the villagers is to be cnlisted by offering to pay compensation for damage to their crops by the wild animals. This would take the form of paying the land revenue for the villagers who, in return, would be asked to co-operate in preserving the fauna.

In 1946 there were about 50 thamin in the sanctuary, which number had increased to 150 by 1952 . Apparently thamin had entered the sanctuary from the unclassed forests of the Thaw range, where there were about 400 to 600 .

Constituted : 10.10.

Slirvczellazo

Area : 213 square miles.

Purpose: Sanctuary for gaur, sambar, thamin and barking-decr.

In this sanctuary there are not less than 250 thamin, fifty gaur and cighty tsaing, besides pig, sambar and barkingdeer. The insurgents regarded the Shwezettaw as sacred and nobody was allowed to shoot in it. When, in March 1955, 
the sanctuary was re-occupied, thamin and barking-deer were so tame that one Chin officer reported that he had shot as many as fourteen animals in a single day. Soon afterwards he was mauled by a bear and admitted to hospital.

During the visit of the Prime Minister and the Home Minister to the Shwezettaw pagoda festival, held soon after re-occupation, the Divisional Forest Officer, U Su, took the opportunity, with the approval of the Prime Minister, of giving a lecture on fauna preservation.

Constituted : 1018.

\section{Maymyo}

Area : 40 square miles.

Purpose: Sanctuary for barking-decr, junglefowl, partridge and peafowl.

During the war and the initial stages of the British re-occupation, hunting was uncontrolled. But since 1947 the game rules were enforced and a successful appeal to preserve the animals was made to the military.

Barking-deer exist in fair numbers; tiger, leopard, wild dog and wild cat are to be found.

This sanctuary, close to the popular hill station of Maymyo, could be developed into a popular national park.

Constituted : 1024.

Moscos Islands

Area : 10 square miles.

P'urpose : Sanctuary for sambar, barking-decr, and pig.

These islands were stocked between 1924 and 1929 with animals whose disappearance from the mainland was feared. Nine sambar, three barking-deer, four hog-deer, nine pigs and two junglefowl were released. Only pigs remain.

Of the indigenous fauna the crab-cating monkey is well represented. 'There is a great variety of birds. Hornbills and imperial pigeons are numerous.

The collection of the edible nests of the grey-rumped swift is authorized. To preserve these birds, nest collecting should at lenst be restricted.

Constituted : 1030.

\section{Welligan}

Arca : 1 s square miles.

P'urpose : Sanctunry for waterfowl.

A lake and marsh sanctuary, suggested by Kan Kyaung Sayadaw, head of the monastery on the lake shore. The sanctuary is reviving from the war years when ponching of waterfowl and fish were rife, but unfortunately the water in the lake is very low. The cause is not certainly known but is 
attributed to the wholesale cutting of cutch trees under permits issued by the insurgents. The sanctuary is being well looked after and the birds are increasing. During cold weather hundreds of duck and teal are to be seen on the lake.

Constituted : 10.12 .

Kelatha IIill

Area : $0 \frac{1}{2}$ square miles.

Purpose: Sanctuary for junglefowl and other birds.

This sanctuary was suggested by the leading monk of Kyaungtaya-Myathabeik monastery. Besides birds, barkingdeer and serow have benefited.

\section{Unofficial Gane Reserves}

In the Southern Shan States there are eight unofficial game reserves in areas outside forest departmental control. Five reserves are situated in Yawnghwe State, two in Lauksawk State and onc in Kengtung States.

They were maintained by the Chiefs in the interests of wild life protection. All these reserves are frequented by large numbers of duck and waterfowl which, together with the fish, are protected by the Chiefs under the customary law. With the recent change in the administration of the Shan States, how these unofficial reserves will fare in the future is not known.

\section{Proposals for New Sanctuaries}

IItu Lake.-In 1940 the villagers in the neighbourhood asked that this lake should be made a sanctuary. Now that political conditions in this area have improved, it is hoped that at long last the villagers' wish may be granted.

IIlain Yoma IIills.-This is the catchment aren of Rangoon water supply dam at Gyobyu. It could become a recreation area for Rangoon.

Byingye IIill.-This would save from extermination the remaining accessible goral in the Union of Burma.

Kyaukpandaung IIill.-The hill forms a horse-shoe platenu, the inner and outer rims of which are precipices. The seenery is magnificent. The state of the wild life in this remote area is uncertain, but it used to contain a herd of gaur and offered unrivalled opportunities for close obscrvation of scrow and goral.

The Chins are a law-abiding people. They are not likely to break the game laws when the area has been made a wild life sanctuary. 


\section{Tire Future}

Before the war the Game Department consisted of a game warden, an inspector, and nineteen others. It is now only two game rangers and nine others. The reason given by Government for its refusal to revive the post of game warden has been that, in the midst of civil war there was nothing for him to do. This excuse is no longer valid.

If the wild life of Burma is to recover, even survive, a game warden is essential. But even the revival of the post of game warden will be of little use unless it is possible to stimulate a general interest in the matter and create a healthy public opinion in favour of giving the harmless members of the fauna reasonable chance to survive. It will be a reproach to the present A.F.P.F.L. Government and irretrievable loss to future generations if no practical measures are undertaken to stem the destruction of wild life.

Two commendable acts show that Government is beginning. to realize that action to protect yild life is necessary. The Frontier Development Enquiry Commission on the China frontier found that takins were being shot in large numbers with poisoned arrows, as they came down in hundreds to the hot springs. Thereupon Maha Thray Sitthu U Shan Lone, O.B.E., MI.C., requested that the shooting of takin should be prohibited. The necessary order was at once made by Duwa Zau Lun, Kachin State Minister.

On the 5th March, 1955, Thiri Pyan Chi U Chit Pe, Secretary, Ministry of Forests and Agriculture, asked the Ministry of FIome Affairs and the War Office to prohibit the shooting of thamin.

\section{REFERENCE}

U 'IUN YIN. IVild Life Preservation and Sanctunries in the Union of Burma. Journal of the Bombay Natural IIistory Society, Vol. 52, Nos. 2 and 3. (With kind permission of the Editors.) 